\title{
Adjustment of Teen-aged Athletes in Badminton Boarding School
}

\author{
Veronica Anastasia Melany Kaihatu \\ Department of Psychology \\ Pembangunan Jaya University \\ Tangerang, Indonesia \\ veronica.kaihatu@upj.ac.id
}

\author{
Adriatik Ivanti \\ Department of Psychology \\ Pembangunan Jaya University \\ Tangerang, Indonesia \\ adriatik.ivanti@upj.ac.id
}

\author{
Supriyanto \\ Department of Psychology \\ Pembangunan Jaya University \\ Tangerang, Indonesia \\ supriyanto@upj.ac.id
}

\begin{abstract}
Indonesia has a badminton boarding school where teenaged badminton athletes can be trained and schooled in the game of badminton in order to obtain optimum result and high performance both in national and international competitions. It became imperative for some adjustments to be made on the school to enable athletes manage the stress and tension arising from the game and to enable them give their best performance. This qualitative case study was used to describe the adjustment process in the athletes. Data was collected from twenty four athletes and four teachers using the semi-structured interview technique. The researchers also focused on the school's principal, teachers and trainers. Results obtained showed that new athletes admitted into the school required one to three months to adjust to the whole boarding system. Furthermore, students are needed to adjust to new school rules and regulations once every six months which is in line with the school's academic calendar and championship outcomes. Results also showed that most athletes managed to carry out unstructured adjustments in an effort to neutralize any negative emotion instead of addressing the core problem. Unsolved problems tend to reappear, thereby, making these students to undergo a slow adjustment process.
\end{abstract}

\section{Keywords—adjustment, teen, athlete, badminton}

\section{INTRODUCTION}

Indonesia is one of the countries in the world believed to have the best badminton players. Unfortunately, this glory is fading away owing to the slow regeneration of badminton players. Jaya Raya School of Badminton (Sekolah Bulutangkis Jaya Raya - SBJR) is one of schools set up to correct the various inconsistencies associated with the game of badminton in Indonesia. The institution is form of a boarding school specifically for badminton athletes who are in the middle and high school age. Athletes interested in the game of badminton are required to go to school where they are groomed in a series of activities, time management skills, rules, and where they are well supervision in an effort to achieve success [1].

Those who live in boarding school or dormitories are required to make effective adjustments [2] or it will it would be pretty difficult from to cope. SBJR aim is to improve young athletes skills by eliminating stress, and other negative ailments affecting their performance. However, the variable capable of affecting these athletes overall performance is the fact that they are still teenagers. Teenagers tend to expereince stress, due to physical, social and psychological changes, thereby, making adjustment an important requirement for the develoment of good mental health in adolescents [3].

Physical and psychological conditions are also influenced with regards to how individuals make adjustment. Those that eventuallysucceed will be able to deal with difficult situations while those who fail will create incorrect behavior patterns.

Athlete's adjustment to SBJR is very important and needs to be revealed because of the unique nature of teenagers. These teenagers are to be helped in pursing their athletic dream until they are able to make great achievements. Previous researches related to the life of teenagers in the dormitories was focused on religion such as pesantren (Islamic boarding school) [3,1,2]. However, SBJR is nonreligious school and a non-specialized school as it teachers her students general sports skills (Sekolah Keberbakatan Olahraga - SKO). It is operated in accordance to the Indonesian curriculum [4]. SKO is categorized as a special education for students of extraordinary abilities so that they can produce high achievements in the field of sports [5].

SBJR specializes in badminton using a tailor made curriculum capable of raising its own characteristics to generate a unique adjustment process in its own dynamics. This process will assist the SBJR in developing an education and training programs to meet the needs and requirements of their athletes. In the end, it will increase an athlete's ability to understand oneself, use better strategies to solve personal problems, and to overcome stressful situations.

\section{LITERATURE REVIEW}

\section{A. Athletes of Jaya Raya School of Badminton}

Jaya Raya School of Badminton (SBJR) was initiated by Jaya Raya Badminton Club to expose teen-aged athletes to academic lives, , and to help them succeed. SBJR integrates academic curriculum into it programs to enable athletes have access to formal education. Every school day, athletes practice badminton in the morning after which they would attend school for 3 hours, from Monday through Friday (Putri, 2016). Athletes are divided into two groups based on 
age namely; youth group starts from 12 or 13 to 15 years old and juvenile group starts from 15 to 18 or 19 years old. Those in the youth group went to the middle school while those in the juvenile group went to high school.

SBJR's routine calendar consists of weekly 5 days of practical lessons, with Sundays and Wednesday set asides as resting days[6]. Each practicing day starts at five o'clock with morning physical exercise followed by a 3 hours' academic activities at school, and ending with evening physical exercises which ends at seven. Practices are conducted according to each athlete's party. In badminton, athletes are divided into five categories namely men's singles, women's singles, men's doubles, women's doubles, and mixed doubles. Of all these parties, single parties are considered more prestigious than double parties, while mixed doubles parties were considered the least in the food chain. Irrespective of their various groups, routine practices are carried out to ensure that athletes perform well in competitions. Outside the routines, athletes are free to choose their activities. Some of them might choose to wonder about the city while others choose to have additional exercises.

The School supervised and trained a total of eighty athletes between the ages of 12 to 18 in a chronologically classified sequence [6]. Research has it that teenagers period are associated with biological, cognitive and socio-emotional changes. Hence, an effort is made by the school to identify who these students really are and where to direct their lives. Adolescents tend to develop a perspective way of thinking about the social world and interpersonal interactions carried out by people around them, developing individual relationships with group members and developing relationships between them and others. Adjustment is an important feature associated with the developmental task which must be carried out by teenagers as they embark on their journey to adulthood. This skill will help them balance their needs with their environmental conditions.

\section{B. Adjustment and Athlete's Performance}

An athlete's overall competitive performance, can be attributed to the result of stamina, strength, flexibility, coordination, skill and ability to play [7]. A lack of concentration as a result of adjustment, anxiety or stress will negatively affect the, the competition itself. However, these outlined information is no news to Jaya Raya Badminton Club. This is because stress is one of the major challenges faced by their athletes. H. Widiani,explained this in his research work using 50 badminton athletes of Jaya Raya Badminton Club in which he beamed that four sources of stress existed, namely (1) physical stressor or physiological demands on the athlete, (2) social stressor or source of stress arising from interaction with other individuals, (3) psychological stress arising from frustration, anxiety or conflict, and (4) endemic stress that cannot be avoided or caused by factors beyond individual control such as grief.

Stress is manageable. Reference [6] explains that there are some characteristics that help athletes manage stress successfully. These characteristics include ability to relax through physical activities, being able to relax without depending on the instructor's orders, being able participate in comfortable and soothing activities, ability to master match techniques and strategies, ability to develop mental strategies, being able to build trust and ability to provide meaning proportional to defeat. However, the research findings from a study carried out at Jaya Raya Badminton Club concluded that not all athletes are capable of dealing with stress.

One of the many ways to deal with stress is to make adjustments. Adjustment is defined as a psychological process of facing challenges in daily life that includes adaptation, coping and managing oneself [9]. Adjustment occurs when individuals try to manage various internal and external demands. It influences an individual's physical, mental and emotional conditions. Those who adjust well will be able to deal with difficult conditions and emerge successful, while those who are unable to deal with difficult situations potentially create incorrect behavior patterns, feel depressed, susceptible to conflict with little or no motivation.

To successfully carry out human adjustments, an object subjected to the adjustment is needed. Therefore, it is imperative to have a thorough understanding of the context. Context such as the historical, economic, social and cultural settings that affect individuals [9]. There is a positive relationship between adjustments with the environment. When an individual's characteristic matches the environmental characteristics, then it can be said that the individual has adjusted effectively [10]. In this research, SBJR is the context.

\section{METHOD}

\section{A. Research Design}

This research work made use of the qualitative research design to understand and have an overview of subjective human experience [11] and to focus on the meaning given to events that occur throughout life.[12]. There are some strengths associated with case studies such as, understanding the context and process, understanding the cause of a phenomenon, encouraging the formation of a new research hypotheses and questions [13]. In addition to these, its strategy is integral to the formulation of research questions specific to certain populations, such as the athletes of SBJR.

\section{B. Data Collection}

- Data (Personal and demographic data) were collected using personal data sheet before conducting an interview. The sheet provided an overview of athlete, such as his education, training schedule, situation of the dormitory and their achievements in badminton. These data were used to accelerate rapport building with regards to personal matters related to adjustment. Data were further collected by interviewing individual athletes, focus group, teachers, headmistress, and a coach. This made it possible for an answer to be compared with others, notwithstanding the fact that it still gave room for flexibility and the exploration of further information [14]. Interviews and the discussion explored each athlete's background to badminton and the process they underwent to gain admission into SBJR. It was also used to explore the similarities and differences between SBJR and other badminton clubs, the strengths and weaknesses of SBJR, things that support and block their adjustment process, their difficulties in adapting and how they manages their situation 


\section{Research Participants}

Initially, data was collection from 15 athletes but as the research proceeded the number was increased to 24 athletes, consisting of 14 girls and 10 boys. Information related to the participants can be seen in Table I. These participants were selected from a approximately 80 athletes in SBJR. The participants were chosen based on mutual consensus between the research team, coaches, teachers and board administrators. This selection was done after some features such as training schedules and matches, priority of players based on achievement ranking, priority of players based on recommendations of coaches, teachers and boarders were considered.

The process of taking and prioritizing the sample was mutually agreed by the research team, trainers, teachers and dormitory administrators. Participants vary in terms of sex, age, duration of living in dormitory, group and parties with several considerations such as training and competition schedules, ranks and recommendations. Meanwhile, additional data were collected with the use of the focus group discussion (FGD) with the help of SBJR's headmaster, 10 teachers and a female coach in-charge of the administration of the dormitories. . In the FGD, previous data were verified or elaborated using the data obtained from different people and different point of view.

DEMOGRAPHIC DATA OF ATHLETE PARTICIPANTS

\begin{tabular}{|c|c|c|c|c|}
\hline Age & Sex & Education & $\begin{array}{c}\text { Duration in } \\
\text { SBJR (month) }\end{array}$ & $\begin{array}{c}\text { Frequency } \\
\text { (person) }\end{array}$ \\
\hline 12 & Female & Middle School & 6 & 1 \\
\hline 13 & Female & Middle School & 2 & 1 \\
\hline 13 & Female & Middle School & 4 & 1 \\
\hline 13 & Female & Middle School & 6 & 1 \\
\hline 14 & Female & Middle School & 2 & 1 \\
\hline 14 & Female & Middle School & 3 & 1 \\
\hline 14 & Female & Middle School & 6 & 2 \\
\hline 15 & Female & Middle School & 0,5 & 1 \\
\hline 15 & Female & Middle School & 12 & 1 \\
\hline 13 & Male & Middle School & 3 & 1 \\
\hline 13 & Male & Middle School & 12 & 1 \\
\hline 14 & Male & Middle School & 3 & 1 \\
\hline 14 & Male & Middle School & 6 & 1 \\
\hline 16 & Female & High School & 6 & 2 \\
\hline 16 & Female & High School & 12 & 1 \\
\hline 17 & Female & High School & 12 & 1 \\
\hline 16 & Male & High School & 8 & 1 \\
\hline 16 & Male & High School & 12 & 1 \\
\hline 17 & Male & High School & 12 & 1 \\
\hline 17 & Male & High School & 18 & 2 \\
\hline 17 & Male & High School & 24 & 1 \\
\hline
\end{tabular}

\section{RESULTS}

Jaya Raya Badminton School (SBJR) was able to convince various individuals to become athletes owing to the fact that it is built by Jaya Raya Badminton Club, one of the most prestigious clubs in Indonesia which is known for training and sending a good number of their athletes to the National Training Centre of Indonesian Badminton Association (Pemusatan Latihan Nasional - Pelatnas) and winning national and international competitions. Therefore, anybody who wants to pursue a serious carrier in badminton should consider gaining entrance into Jaya Raya Badminton Club. Results showed that all athletes were exposed to badminton from childhood ad some their early days in elementary school (SD). Most of these athletes have been badminton athletes for more than 3 years. Initially they joined small local clubs or other national clubs, but now they live in a facility aimed at supporting their badminton and academic abilities to achieve optimal performance. Their joy as members of SBJR is written all over their face.

\section{A. Adjustment to SBJR}

The participants agreed that the benefits they received from SBJS were accompanied by adequate responsibilities. The training and championship targets given to them were incomparable to those given to them by former club. However, they just have to abide by these rules and tasks to achieve success. . SBJS coaches beamed that the newly admitted athletes have moved to different parties since then. Athletes who were initially in the singles party have moved to the doubles or mixed doubles party because they were unable to perform in the previous parties. The changes were initiated by coaches based on the assessment of each athlete performance during training..

Changing from one party to another is stressful and challenging , especially from singles to doubles for a badminton athlete. This is because it will affect the athlete's opportunity to enter a championship and future performance. However, changes are based on each athlete's physical ability and performance. Therefore, participants who were advised to switch parties eventually accept to do so because they recognize their inability to participate in training programs belonging to other parties which seems higher than their capabilities and abilities. When participants experience achievement in their new party, the stress will eventually fate away.

All participants managed themselves by being more disciplined and punctual after joining SBJR. This change of behavior has a clear effect on participants in terms of training motivation. Those who were admitted into the double parties were required to foster good relationships with their partners because it is closely related to their later achievements. Some athletes opted for two or three parties because they had not fully stepped down from their original party. However, they soon realized that their decision was influential to the duration of the exercise with little or no rest. Participant's commitment to themselves and others will determine their success the expected behaviors.

\section{B. Adjustment to Boarding School}

Most participants stated that moving into a dormitory and getting separated from their family had a significant impact 
on their lives and this is something that needs to be understood and seriously taken into consideration by all SBJR athletes. The stress associated with SBJR dormitory, school and badminton court becomes unbearable when expectations are not in accordance with the reality. A teenager who has just been accepted into one of the prestigious clubs of SBJS, must now compete with other teenagers to achieve success.. Making friends, having access to the right information, and getting help from others is essential but these could be difficult to achieve if you are yet to get acclimatized to the new environment.

Participants who experienced severe stress turn to their families through the use of various electronic gadgets. However, the use of these gadgets is limited according to dormitory regulations as they are collected before bed time. A good number of middle school participants interviewed stated during their first three months in the institution, they often cried of being lonely. High school participants get over this within a space of one month.

All SBJR athlete, soon realized that they must be able to depend on themselves irrespective of the situation. Coaches have already given them some heads up about right from the onset but they claimed to have forgotten about it. They acknowledged that some imminent conditions ultimately forced them to behave with respect to their needs. Some participant resulted to doing things that are beneficial to others as a way of making new friends. This bridges communication gap, by creating a communication channel, thereby, bringing these athletes closer. In addition to this, some middle school participants stated that they tried to get acquainted and foster good relationships with athletes who were older, such as high school athletes, to lower the competitive feeling.

\section{Adjustment to Competition}

a) Badminton athletes have certain points achieve to ensure they are victorious in each match. Therefore, participating in championship competitions would have a huge influence on the athlete's career. Depending on the type of competition, a defeat does not automatically exit an athlete, but the position or points of the athlete given by the coach does.

b) All participants understood the system and were concerned of their points, the points of the opponent and the target position they are trying to achieve. Facing an everchanging situation, it is crucial to have comprehensive information. The internet is used by all participants to gather information and learn the techniques, physical conditions and styles their opponent. However, having access to this information could either lead to victory or lose. Most participants would lose their enthusiasm and courage if they knew their opponents capability. Meanwhile, having prior knowledge of a stronger opponent capability would make the competition burdensome.

c) Training is the ultimate technique used prepare for a match. Athletes of SBJR are trained by their coaches to improve their skills. A coach's role is to improve the skills and make them competent to face their future opponents or championship. All participants stated that the SBJR training program was pretty tasking; nonetheless confident participants with good achievement had additional independent training hours. They feel the need to train without the coach makes them more relaxed. In addition, they also feel that these independent training hours allows them to apply all techniques learnt from the coach without being reminded. It makes them confident and feel more prepared to participate a championship.

\section{CONCLUSION}

Teen-age athletes of SBJR do not only undergo physical and mental changes but they also undergo social changes that continuously occur within the facility. They faced greater challenges comparing to other teenagers because they have decided to get committed to badminton and the dormitory environment.. SBJR as a system provides further social changes which requires athletes to make adjustments in order to function optimally. They were expected to achieve targets continuously despite facing individual problems and without having the proper mental skill.

Athletes' efforts were limited to their mood and temporary emotional conditions. When they got tired or bored, they sleep or listen to music without considering what the outcome would be to their future. When they longed for their family, they secretly used a spare cellphone to get in contact with them.. Their goal is to improve their mood so that they can return to training feeling quite well. The problems that The inconsistencies associated with athletes emotions, if not properly addressed will remain a reoccurring phenomenon

Athletes facing these conditions, need to be equipped with skills to adjust, if they must o have a healthy and fruitful carrier. A good understanding of the situation and conditions, and ability to identify the pressure would go a long way. Furthermore, the athletes could determine the fundamental problems they are facing and came up with alternative solutions. They would not only eliminate negative emotions but also solve problems in a healthy manner and could build new commitments according to their needs.

\section{REFERENCES}

[1] N. Zakiyah, F. N. R. Hidayati, and I. Setyawan, "Hubungan antara penyesuaian diri dengan prokrastinasi akademik siswa sekolah berasrama SMPN 3 Peterongan Jombang," Jurnal Psikologi Undip, 2010. vol. 8, no. 2 ,

[2] S. Maslihah, "Studi tentang hubungan dukungan sosial, penyesuaian sosial di lingkungan sekolah dan prestasi akademik siswa SMPIT Assyfa boarding school Subang Jawa Barat,” Jurnal Psikologi Undip, 2011. vol.10, no. 2,

[3] N. Wijaya, "Hubungan antara keyakinan diri akademik dengan penyesuaian diri siswa tahun pertama sekolah asrama SMA Pangudi Luhur Van Lith Muntilan," unpublished.

[4] Mendikbud ajak Pemda kembangkan Sekolah Keberbakatan Olahraga. Available from: http://www.suara.com/news/2016/09/25/105256/mendikbud-ajakpemda-kembangkan-sekolah-keberbakatan-olahraga.

[5] Fauzi, "Special education service for talented children on sport," Jurnal Olahraga Prestasi, 2010, vol. 6, no. 1,

[6] D. Putri, "Gambaran Penerapan Managing Anxiety pada Atlet Tunggal Taruna di Klub Bulu Tangkis XYZ,” unpublished.

[7] H. Widiani, "Sumber stres dan strategi coping pada pelajar atlet bulu tangkis," unpublished.

[8] D. Putri, V. A. M. Kaihatu, and A. Ivanti. "Gambaran Penerapan Managing Anxiety pada Atlet Tunggal Taruna di Klub Bulu Tangkis XYZ." [Proceeding of Seminar Nasional \& Call for Paper Psikologi 
Indigenous Indonesia 2016, p. 633-657]. Available from https://drive.google.com/file/d/0B5En8gKufpbneTdkeVBmalMyRDQ /view.

[9] J. W. Santrock, Human adjustment. New York: McGraw-Hill, 2006.

[10] C. E. Amiot, , R. J. Vallerand, and C. M. Blanchard, "Passion and psychological adjustment: A test of the person-environment fit hypothesis," Personality and Social Psychology Bullletin, 2006, vol. 32 , no. 2, pp. $220-229$, February

[11] J. F. Gilgun, "Qualitative research and family psychology," Journal of Family Psychology, 2005, vol. 19, no. 1, pp. 40-50,
[12] J. F. Gilgun, "Qualitative family research: Enduring themes and contemporary variations" in Handbook of Marriage and the Family, $3^{\text {rd }}$ ed, G. W. Peterson and K. R. Bush, Eds. New York: Spinger Science+Business Media, 2013.

[13] B. Flyvbjerg, "Case study" in The SAGE Handbook of Qualitative Research, $4^{\text {th }}$ ed, N. K. Denzin and Y. S. Lincoln, Eds. London: Sage Publication, 2011.

[14] J. Kothari, Research Methodology: Methods and Techniques. New York: New Age International, 2004 